\title{
Boron Hydrogen Compounds for Hydrogen Storage and as Solid lonic Conductors
}

\author{
Hans Hagemann*
}

\begin{abstract}
Metal borohydrides have been studied since the beginning of this century as potential hydrogen storage materials due to their high gravimetric hydrogen content. Many new compounds have been synthesized and characterized, however to date the main problem are the kinetics of dehydrogenation and rehydrogenation. In this review we address thermodynamical and chemical properties of boron hydrogen compounds which come into play for hydrogen storage and which must be considered in the search for efficient catalysts. More recently, closo and nido hydridoborate and related closo hydridocarborate compounds have been identified as good ionic conductors for all-solid-state lithium or sodium batteries. The properties of these fascinating and very promising compounds for battery applications are illustrated with recent literature results.
\end{abstract}

Keywords: Boron chemistry · Hydrogen storage · Ionic Conductors · Solid-state Batteries

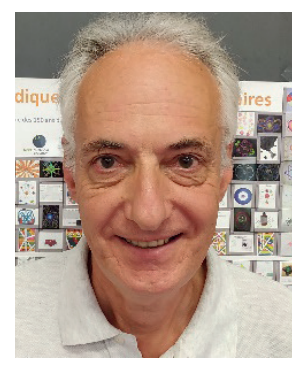

Hans Hagemann obtained his PhD in 1984 in the field of Raman spectroscopy on layered crystal under the supervision of Prof. Hans Bill. After a postdoctoral stay at UC Berkeley with Prof. H.L. Strauss and Dr. R.G. Snyder, he returned to the University of Geneva. His research interests are solidstate chemistry, lanthanide spectroscopy, hydrogen storage materials and more recently also new battery materials. Since 2011, he is also the scientific supervisor of the Chimiscope, the chemistry outreach platform of the Faculty of Sciences of the University of Geneva (https://scienscope.unige.ch/chimiscope/).

\section{Introduction}

The transition towards a sustainable energy supply for humankind is a challenging task for ongoing and future research. This implies energy production using solar cells or wind parks, local and portable energy storage, and energy transport. In this review, we will focus on metal boron hydrogen compounds, which can be considered both for hydrogen storage as well as for solid-state ion conductors for new all-solid-state batteries.

Hydrogen is considered to be a major energy vector, ${ }^{[1]}$ however pure hydrogen gas has a rather poor volumetric energy compared, for instance, to gasoline at ambient temperature and pressure. For automobile applications using hydrogen fuel cells to generate electricity on board, several hydrogen storage concepts have been and continue to be considered: hydrogen gas at high pressures (700 bar), liquid and solid hydrogen storage compounds.

These storage materials must satisfy the following criteria for potential automobile applications: ${ }^{[2,3]}$ high gravimetric hydrogen content, high volumetric hydrogen content, thermodynamic constraints, kinetic constraints, safety and price.

The gravimetric and volumetric hydrogen content which should be achieved is illustrated by the American DOE ultimate target values (updated 2017):[3] $0.065 \mathrm{~kg} \mathrm{H}_{2} /(\mathrm{kg}$ system) and

${ }^{*}$ Correspondence: Prof. H. Hagemann, E-mail: hans-rudolf.hagemann@unige.ch Dépt. de Chimie Physique, Univ. de Genève, 30, quai E. Ansermet,

CH 1211 Geneva 4
$0.05 \mathrm{~kg} \mathrm{H}_{2} /(1 \mathrm{system})$. The system comprises the complete storage system with the storage material, container, etc. The thermodynamical constraints result on one side from safety considerations (no spontaneous evolution of hydrogen) and from, on the other side, efficiency considerations (not too much energy should be lost in the chemical hydrogen storage process). Typically, considering that the entropy change for the hydrogen gas release from the solid storage material is about $120 \mathrm{~J} /\left(\mathrm{mol} \mathrm{H}_{2}\right)$. K, one obtains a corresponding optimal enthalpy value of about $30-50 \mathrm{~kJ} / \mathrm{mol}$ $\mathrm{H}_{2} \cdot{ }^{[2]}$ Further, the reaction should of course be reversible and allow for rehydrogenation (under high hydrogen pressure).

The kinetic constraint would be to fill a tank in useful time (3-5 min). [2] This aspect is currently the real bottleneck for practical applications using complex hydrides such as borohydrides or alanates as hydrogen storage materials.

Among the potential solid hydrogen storage materials, metal borohydrides have been studied for this application since about 20 years, and many new compounds have been prepared and characterized..$^{[4-10]}$ For instance, the compound $\mathrm{Mg}\left(\mathrm{BH}_{4}\right)_{2}$ has a hydrogen content of 14.9 mass\%.[11,12] This compound can be prepared in different crystalline modifications, and high-pressure phase transitions have also been observed. ${ }^{[12]}$ The dehydrogenation reaction:

$$
\mathrm{Mg}\left(\mathrm{BH}_{4}\right)_{2} \rightarrow \mathrm{MgB}_{2}+4 \mathrm{H}_{2}
$$

is in fact a multistep reaction with various reaction intermediates such as $\mathrm{Mg}\left(\mathrm{B}_{3} \mathrm{H}_{8}\right)_{2}, \mathrm{MgH}_{2}$ and $\mathrm{MgB}_{12} \mathrm{H}_{12}{ }^{.11,13]}$ It has been shown that $\mathrm{MgB}_{2}$ can be rehydrogenated under a pressure of 950 bar at $450{ }^{\circ} \mathrm{C},{ }^{[14]}$ providing thus a proof of concept that this material is indeed a potential candidate for hydrogen storage.

In this review, we start with thermodynamical and chemical considerations regarding the general chemistry of boron hydrogen species in view of hydrogen storage. We then consider the hydrogen release reactions of $\mathrm{Mg}\left(\mathrm{BH}_{4}\right)_{2}$ in more detail. The understanding of the detailed reaction mechanism involved for hydrogen release and hydrogen uptake may then allow to search very specifically for appropriate catalysts to improve and optimize the kinetics. Closo hydridoborates such as $\mathrm{MgB}_{12} \mathrm{H}_{12}$ can possibly act as a thermodynamic sink for hydrogen storage applications due to 
their high stability. ${ }^{[13]}$ On the other hand, this type of big anions (closo hydridoborates, nido hydridoborates, closo hydridocarborates) has been shown in the last years to form compounds with very high ionic conductivity for lithium and sodium in the solid state. ${ }^{[15-29]}$ Recent results on these potential applications will be presented in the last part.

\section{Thermodynamic and Chemical Considerations}

The thermodynamic properties of boranes have been addressed both theoretically and experimentally. ${ }^{[30-34]}$

In Fig. 1, the normalized formation enthalpy per boron atom of various boranes in the gas phase is shown as a function of the ratio $\mathrm{H} / \mathrm{B}$.

Fig. 1 shows as a general trend that typically below the H/B ratio of 1 , the formation enthalpy increases strongly. Going from $\mathrm{B}_{5} \mathrm{H}_{11}$ to $\mathrm{B}_{5} \mathrm{H}_{9}$ is exothermic $(-30 \mathrm{~kJ} / \mathrm{mol})$, thus $\mathrm{B}_{5} \mathrm{H}_{11}$ does not appear to be a candidate for hydrogen storage. In contrast, going from $\mathrm{B}_{4} \mathrm{H}_{10}$ to $\mathrm{B}_{4} \mathrm{H}_{8}$ is associated with $\Delta \mathrm{H}=+40 \mathrm{~kJ} / \mathrm{mol}$, which would be a desirable value, but then going from $\mathrm{B}_{4} \mathrm{H}_{8}$ to $\mathrm{B}_{4} \mathrm{H}_{6}$ has $\Delta \mathrm{H}=+75 \mathrm{~kJ} / \mathrm{mol}$. The global transition from $\mathrm{B}_{4} \mathrm{H}_{10}$ to $\mathrm{B}_{4} \mathrm{H}_{6}$ would correspond to a hydrogen mass fraction of $7.5 \%$, which is in principle in the range of target values for hydrogen storage. However, boranes have not been considered for hydrogen storage. The lighter boranes are gases at ambient temperature and pressure, $\mathrm{B}_{5} \mathrm{H}_{9}$ is liquid (boiling point $60{ }^{\circ} \mathrm{C}$ ) and $\mathrm{B}_{10} \mathrm{H}_{14}$ is solid. Further, boranes are toxic, ${ }^{[35]}$ and very reactive. Note that boranes have been considered as potential fuels many years ago.[36]

In Fig. 1, the formation enthalpy data for some anionic species are also displayed. The first observation is that these anions are more stable than the neutral boranes. The addition of a hydride ion $\left(\Delta_{\mathrm{f}} \mathrm{H}^{\circ}(298 \mathrm{~K})=145.2 \mathrm{~kJ} / \mathrm{mol}\right)$ to a neutral borane is very exothermic for $\mathrm{BH}_{3}, \mathrm{~B}_{2} \mathrm{H}_{6}, \mathrm{~B}_{3} \mathrm{H}_{7}$ and $\mathrm{B}_{4} \mathrm{H}_{8}$, which reflects the strong Lewis acid character of the neutral boranes. On the other side, the anions $\mathrm{BH}_{4}^{-}, \mathrm{B}_{3} \mathrm{H}_{8}^{-}$and $\mathrm{B}_{4} \mathrm{H}_{9}^{-}$and $\mathrm{B}_{9} \mathrm{H}_{14}^{-}$have been reported to react with one molar equivalent of the Lewis acids $\mathrm{BX}_{3}(\mathrm{X}=\mathrm{Cl}, \mathrm{Br}, \mathrm{I})$ to form $\mathrm{B}_{2} \mathrm{H}_{6}, \mathrm{~B}_{4} \mathrm{H}_{10}, \mathrm{~B}_{5} \mathrm{H}_{11}$ and $\mathrm{B}_{10} \mathrm{H}_{14}$, respectively. ${ }^{[37]}$ The initial step of these reactions is the removal of hydride to form $\mathrm{BHX}_{3}^{-}$species.
These reactions show that in condensed phase, hydride ions can be removed or added, depending on the strength of the Lewis acids present. In this context it may be interesting to note that the mixtures of $\mathrm{NaBH}_{4}$ and $\mathrm{NaBF}_{4}$ release hydrogen at much lower temperatures than pure $\mathrm{NaBH}_{4}\left(300{ }^{\circ} \mathrm{C}\right.$ vs $\left.476{ }^{\circ} \mathrm{C}\right)$ and involve equally the formation of $\mathrm{BH}_{x} \mathrm{~F}_{4-\mathrm{x}}{ }^{-}$species. ${ }^{[38]}$ Mixtures of $\mathrm{LiBH}_{4}$ and $\mathrm{LiBF}_{4}$ start to decompose even at $80{ }^{\circ} \mathrm{C}$ and release mixtures of hydrogen and $\mathrm{B}_{2} \mathrm{H}_{6} \cdot{ }^{[39]}$

In view of the hydrogen release reactions of potential hydrogen storage materials, it is useful to review some of the literature available for the synthesis of the larger nido and closo species. Fig. 2 shows a selection of reactions which have been observed. ${ }^{[40-59]}$

The formation of these larger species involves inherently multistep processes which depend on the reaction medium (in solution, suspension or dry), temperature and pressure. Thus, the reaction of $\mathrm{NaBH}_{4}$ with $\mathrm{B}_{2} \mathrm{H}_{6}$ can yield either $\mathrm{B}_{11} \mathrm{H}_{14}{ }^{-}$or $\mathrm{B}_{12} \mathrm{H}_{12}{ }^{2-}$ depending on solvent and temperature. ${ }^{[60]}$ Starting from $\mathrm{NaBH}_{4}$ and $\mathrm{BF}_{3} . \mathrm{Et}_{2} \mathrm{O}$, one forms first $\mathrm{NaB}_{3} \mathrm{H}_{8}$ which then forms $\mathrm{B}_{11} \mathrm{H}_{14}{ }^{-}$. The path for this second reaction is not clear and it could involve either $\mathrm{B}_{4} \mathrm{H}_{10}$ as suggested by the reactions with Lewis acids shown above ${ }^{[37]}$ or other species such as $\mathrm{B}_{5} \mathrm{H}_{9}$. The thermal decomposition of the dioxane solvate $\mathrm{NaB}_{3} \mathrm{H}_{8} \cdot \mathrm{C}_{4} \mathrm{H}_{8} \mathrm{O}_{2}$ at $140{ }^{\circ} \mathrm{C}$ under vacuum produced $\mathrm{NaBH}_{4}, \mathrm{~B}_{5} \mathrm{H}_{9}, \mathrm{H}_{2}$ and dioxane. [61] The fact that $\mathrm{BH}_{4}^{-}$ is also formed during the reaction of two $\mathrm{B}_{3} \mathrm{H}_{8}{ }^{-}$ions is another complication for the understanding of a global reaction process.

Decaborane(14) $\mathrm{B}_{10} \mathrm{H}_{14}$ has been previously prepared in large quantities as solid rocket fuel[62] and can also be used as a starting material for the synthesis of closo hydridoborates and closo hydridocarborates. ${ }^{[63]}$ In aqueous solution, decaborane(14) has also been reported to be a Brönsted acid forming $\mathrm{B}_{10} \mathrm{H}_{13}{ }^{-}$when reacted with a base.[64]

During the decomposition of solid borohydrides, the evolution of $\mathrm{B}_{2} \mathrm{H}_{6}$ can be observed. ${ }^{[65]}$ This is the case for $\mathrm{LiZn}_{2}\left(\mathrm{BH}_{4}\right)_{5}$ which upon heating to $100{ }^{\circ} \mathrm{C}$ releases $\mathrm{B}_{2} \mathrm{H}_{6}$ and $\mathrm{H}_{2} \cdot{ }^{[66]}$ This compound is obtained by ball milling of $\mathrm{LiBH}_{4}$ and $\mathrm{ZnCl}_{2}$, and can thus also act as a solid precursor for the safe generation of diborane gas in the laboratory. ${ }^{[67]}$

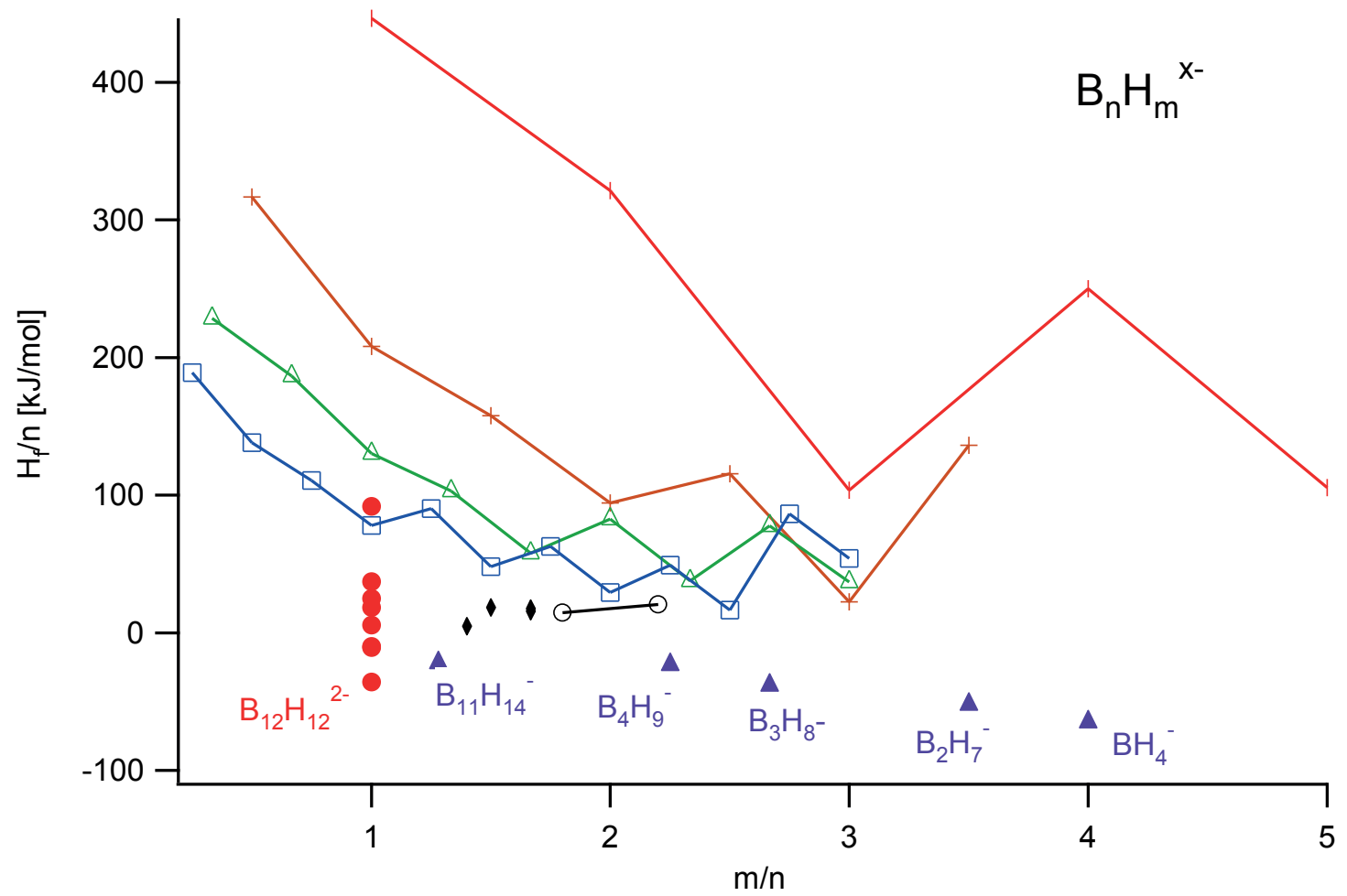

Fig. 1. Formation enthalpy of boranes and boron hydrogen anions in the gas phase, divided by the number of boron atoms as a function of the $\mathrm{H} / \mathrm{B}$ ratio. Red trace (): $\mathrm{BH}_{m}$, brown trace $(+): \mathrm{B}_{2} \mathrm{H}_{m}$, green trace $(\Delta)$ : $\mathrm{B}_{3} \mathrm{H}_{m}$, blue trace $(\square): \mathrm{B}_{4} \mathrm{H}_{m}$, black trace $(O) \mathrm{B}_{5} \mathrm{H}_{9}$ and $\mathrm{B}_{5} \mathrm{H}_{11}$, other boranes $\mathrm{B}_{6} \mathrm{H}_{10}$, $\mathrm{B}_{8} \mathrm{H}_{12}, \mathrm{~B}_{9} \mathrm{H}_{15}$ and $\mathrm{B}_{10} \mathrm{H}_{14}(\bullet)$. The red-filled circles correspond to the closo hydridoborates $\mathrm{B}_{n} \mathrm{H}_{n}{ }^{2-}$ with $\mathrm{n}=5-12$. 




Fig. 2. Illustration of some of the different reaction pathways to form complex closo and nido hydridoborate or closo hydridocarborate anions. ${ }^{[40-59]}$

The thermal decomposition of $\mathrm{Cs}_{3} \mathrm{Y}\left(\mathrm{BH}_{4}\right)_{6}$ or $\mathrm{Cs}_{2} \mathrm{LiY}_{(}\left(\mathrm{BH}_{4}\right)_{6}$ results in the release of $2.9 \mathrm{~mol}_{\text {of }} \mathrm{H}_{2}$ to form the crystalline compound $\mathrm{Cs}_{3}\left(\mathrm{BH}_{4}\right)\left(\mathrm{B}_{12} \mathrm{H}_{12}\right) \cdot{ }^{[68]}$ This example illustrates that there can be a direct reaction pathway from $\mathrm{BH}_{4}{ }^{-}$to $\mathrm{B}_{12} \mathrm{H}_{12}{ }^{2-}$ during the thermal dehydrogenation.

However, in many other cases, it remains very difficult to identify the successive decomposition products, as different reactions may overlap. Nevertheless, the controlled dehydrogenation can also yield new materials. Recently, Zhu et al. reported the preparation of a Li-B-H complex with high ionic conductivity $\left(2.710^{-4}\right.$ $\mathrm{S} / \mathrm{cm}$ at $35^{\circ} \mathrm{C}$ ) by dehydrogenation of $\mathrm{LiBH}_{4}$ at $450{ }^{\circ} \mathrm{C}$ under 3 bar of hydrogen for 20 hours. ${ }^{[28]}$ This Li-B-H complex appears to contain polymerized $\left[\mathrm{Li}_{2} \mathrm{~B}_{12} \mathrm{H}_{11+1 / n}\right]_{n}$ layers which favor $\mathrm{Li}$ ionic conduction.

\section{3. $\mathrm{Mg}\left(\mathrm{BH}_{4}\right)_{2}$ as a Hydrogen Storage Material}

The compound $\mathrm{Mg}\left(\mathrm{BH}_{4}\right)_{2}$ has a hydrogen content of $14.9 \mathrm{wt} \%$, which makes it attractive as a potential solid hydrogen storage material. This compound presents five different crystalline phases depending on the preparation procedure, pressure and temperature. ${ }^{[11-14]}$ It is interesting to note that one of these phases is extremely porous and allows for gas adsorption at low temperatures. ${ }^{[12]}$

The studies on $\operatorname{Mg}\left(\mathrm{BH}_{4}\right)_{2}$, have been reviewed in detail in 2016. ${ }^{[11]}$ Some of the pertinent results will be shown here and recent new results discussed. Fig. 3 illustrates some of the dehydrogenation (in blue) and rehydrogenation reactions (in red) which have been observed.

$\mathrm{MgB}_{2}$ appears to be the final product of dehydrogenation at high temperatures and can be rehydrogenated, although under drastic conditions $\left(950\right.$ bar $\mathrm{H}_{2}$ at $\left.400{ }^{\circ} \mathrm{C}\right) .{ }^{[14]}$ The enthalpy of reaction for the dehydrogenation of $\mathrm{Mg}\left(\mathrm{BH}_{4}\right)_{2}\left(\Delta_{\mathrm{f}} \mathrm{H}^{\circ}=-208 \mathrm{~kJ} /\right.$ $\mathrm{mol})$ to form $\mathrm{MgB}_{2}\left(\Delta_{\mathrm{f}} \mathrm{H}^{\circ}=-91.96 \mathrm{~kJ} / \mathrm{mol}\right)$ and hydrogen can be calculated ${ }^{[69,70]}$ to be equal to $+116 \mathrm{~kJ} / \mathrm{mol}$, i.e. less than $30 \mathrm{~kJ} /$ mol per hydrogen molecule released, which is in principle in the correct range for a hydrogen storage material. ${ }^{[2]}$ However, as can be seen in Fig. 3, kinetic properties appear to be the limiting factor for the efficient hydrogen release and hydrogen reabsorption.

As seen above, the first step of a dehydrogenation reaction of $\mathrm{BH}_{4}^{-}$is likely to be the breaking of a $\mathrm{B}-\mathrm{H}$ bond. Isotope exchange reactions of $\operatorname{Mg}\left(\mathrm{BH}_{4}\right)_{2}$ with $\mathrm{D}_{2}$ allow to make a complete exchange to form $\operatorname{Mg}\left(\mathrm{BD}_{4}\right)_{2}$, and the corresponding activation energy was estimated to be about $51 \mathrm{~kJ} / \mathrm{mol} .{ }^{[71]} \mathrm{For} \mathrm{Ca}\left(\mathrm{BH}_{4}\right)_{2}$, the corresponding activation energy was found to be $82 \mathrm{~kJ} / \mathrm{mol}$ and $98.5 \mathrm{~kJ} / \mathrm{mol}$ for the reverse reaction, confirming that breaking of a bond with hydrogen or deuterium is the rate limiting step. ${ }^{[72]}$ Theoretical calculations of potential defects in $\mathrm{Mg}\left(\mathrm{BH}_{4}\right)_{2}$ suggest that in the initial phase of the dehydrogenation a $\mathrm{H}^{-}$ion is formed which can diffuse in the lattice.[73] On the other side, gas diffusion in the solid is also a contribution to the exchange kinetics, as was shown by isotope exchange reactions with the highly porous modification of $\mathrm{Mg}\left(\mathrm{BH}_{4}\right)_{2}$ with a high surface area compared to a ball milled sample with strongly reduced surface area.[74]

The reaction kinetics of hydrogen release in $\mathrm{Mg}\left(\mathrm{BH}_{4}\right)_{2}$ can be significantly enhanced by various additives such as $\mathrm{TiCl}_{3}$ or $\mathrm{NbF}_{5}, \mathrm{TiO}_{2}{ }^{[75,76]}$

Lewis bases in the form of solvates of $\mathrm{Mg}\left(\mathrm{BH}_{4}\right)_{2}$ can also accelerate the hydrogen release. ${ }^{[77]}$ As shown in Fig. 3 , the THF solvate releases $\mathrm{H}_{2}$ gas below $200{ }^{\circ} \mathrm{C}$ to form $\mathrm{Mg}\left(\mathrm{B}_{10} \mathrm{H}_{10}\right)$. The formation of $\mathrm{B}_{3} \mathrm{H}_{8}^{-}$and $\mathrm{B}_{12} \mathrm{H}_{12}{ }^{2-}$ was also observed, however, with THF and dimethylether $\mathrm{B}_{12} \mathrm{H}_{12}^{2-}$ remained a minor reaction product.

$\mathrm{MgB}_{3} \mathrm{H}_{8}$. THF can be rehydrogenated under milder conditions than dry $\mathrm{MgB}_{3} \mathrm{H}_{8}\left(50 \mathrm{bar} \mathrm{H}_{2}\right.$ and $200{ }^{\circ} \mathrm{C}$ for $5 \mathrm{~h}$ vs 120 bar $\mathrm{H}_{2}$ and $250^{\circ} \mathrm{C}$ for $48 \mathrm{~h}$ ). ${ }^{878]}$ The rehydrogenation of $\mathrm{MgB}_{2}$ can also be accelerated with THF, $\mathrm{MgH}_{2}$ and $\mathrm{Mg} .{ }^{[79]}$ Mechanically milled mixtures of $\mathrm{MgB}_{2}$, THF and $40 \mathrm{~mol} \% \mathrm{Mg}$ could thus absorb $6 \mathrm{wt} \%$ of $\mathrm{H}_{2}$ at $300{ }^{\circ} \mathrm{C}$ under 700 bar of $\mathrm{H}_{2}$, which is less drastic than without THF.

These experiments suggest that while Lewis acids may favor the dehydrogenation reactions of $\mathrm{Mg}\left(\mathrm{BH}_{4}\right)_{2}$, they are not catalyzing the rehydrogenation reactions, as transition metal halides do not appear to affect the rehydrogenation of $\mathrm{MgB}_{2}{ }^{[80,81]} \mathrm{THF}$ and

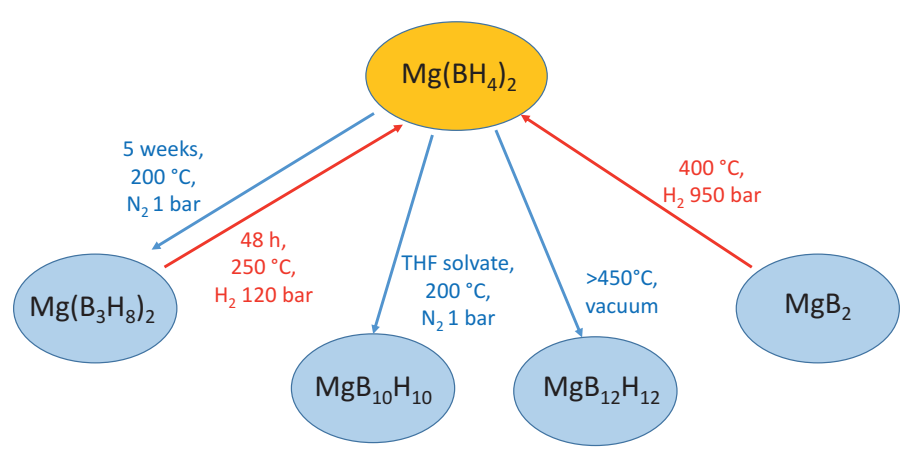

Fig. 3. Selected hydrogenation (in red) and dehydrogenation (in blue) reactions with $\mathrm{Mg}\left(\mathrm{BH}_{4}\right)_{2}$. 
other Lewis bases appear to accelerate both dehydrogenation and rehydrogenation reactions of $\mathrm{Mg}\left(\mathrm{BH}_{4}\right)_{2}$ and encourage further studies to improve the kinetics even more.

Comparative experiments using solvent-free and THF adducts of $\mathrm{Mg}\left(\mathrm{B}_{3} \mathrm{H}_{8}\right)_{2}$ under the same conditions are currently under way and are expected to shed more light on the hydrogenation and dehydrogenation reactions of this material. In parallel, new theoretical approaches to predict the morphology of potential reaction intermediates have been developed and allow to explore the energetics of reaction pathways in this system. ${ }^{[82]}$

\section{Closo Hydridoborates and Related Species as Solid Ionic Conductors}

Solid ionic conductors for lithium or sodium batteries allow the use of a flammable organic electrolyte to be avoided and are thus expected to improve considerably the safety of batteries. A good solid electrolyte must fulfill several empirical criteria, according to ref. [83]: (a) An 'open structure' with a low coordination number of the mobile ion. (b) Presence of structural phase transitions at low pressures. In the case of AgI, the ambient pressure wurtzite structure transforms at $3 \mathrm{kbar}$ and $315 \mathrm{~K}$ into a $\mathrm{NaCl}$ structure going thus from a rather covalent network with coordination number 4 to a rather ionic structure with coordination number 6 . The associated charge fluctuations between ions can potentially be coupled to vibrational motions and favor thus dynamically the ionic conduction. (c) For a material composed of two elements $\mathrm{A}$ and $\mathrm{B}$, the parameter $\mathbf{Z}^{*}$ defined as $Z^{*}=\sqrt{\frac{Z_{A} Z_{B}}{\varepsilon}}$ has a small value $\left(\mathbf{Z}_{\mathrm{A}, \mathrm{B}}\right.$ is the valence of $\mathrm{A}$ and $\mathrm{B}$ and $\varepsilon$ is the dielectric constant). This parameter reflects the polarizability of the material.

For practical applications, the conductivity of the material should be higher than $1 \mathrm{mS} / \mathrm{cm}$. Further, the material should have high chemical and thermal stability as well as a high electrochemical stability window. Additionally, it must be electronically insulating to avoid self-discharge or shortage of the battery. Further, the electrolyte should be deformable in order to accommodate the volume changes of anode and cathode materials upon lithium or sodium insertion and removal. This can thus limit the formation of fractures which reduce the performance of the battery. Finally, the material should not be toxic and cheap enough for the applications considered.

The discovery in 2014 of superionic conductivity in $\mathrm{Na}_{2} \mathrm{~B}_{12} \mathrm{H}_{12}$ above its high-temperature phase transition at $539 \mathrm{~K}$ with a conductivity of $0.1 \mathrm{~S} / \mathrm{cm}$ has stimulated new research for similar compounds with high ionic conductivity at lower temperatures. ${ }^{[15]}$ The ions $\mathrm{B}_{10} \mathrm{H}_{10}{ }^{2-}$ and $\mathrm{B}_{12} \mathrm{H}_{12}{ }^{2-}$ are not very toxic. Mutterties et al. report the $\mathrm{LD}_{50}$ values for $\mathrm{Na}_{2} \mathrm{~B}_{10} \mathrm{H}_{10}$ and $\mathrm{Na}_{2} \mathrm{~B}_{12} \mathrm{H}_{12}$ administered orally to rats to be around or higher than $7.5 \mathrm{~g} / \mathrm{kg}$ of body weight for both compounds. ${ }^{[84]}$

Table 1 summarizes different compounds studied and the conductivities observed at different temperatures. ${ }^{[15-29]}$ Most studies have focused so far on lithium and sodium ionic conductors with closo hydridoborates and related compounds.

The abovementioned criteria of ref. [83] can be expanded for these new borate-based ionic conductors: ${ }^{[18,85]}$

The crystal structure must have many accessible interstitial sites and different types of sites to provide ion diffusion pathways. The comparison of different structure types of closo hydridoborate solid ionic conductors shows that a hexagonal closed packing (hcp), as observed in the partially substituted $\mathrm{Na}_{2} \mathrm{~B}_{12} \mathrm{H}_{12-\mathrm{x}}$ I with space group $\mathrm{P}_{3} \mathrm{mc}$ above $360 \mathrm{~K}$, is very favorable. This packing allows for hops of ions between octahedral and octahedral, octahedral and tetrahedral as well as tetrahedral and tetrahedral sites. It is interesting to note also that different crystal structures for $\mathrm{Na}_{2} \mathrm{~B}_{12} \mathrm{H}_{12}$ are relatively close in energy and depend also on the unit cell volume.
As can be seen from the table, the highest room temperature conductivities have been observed so far for the solid solutions $\mathrm{Na}_{2}\left(\mathrm{~B}_{12} \mathrm{H}_{12}\right)_{0.5}\left(\mathrm{~B}_{10} \mathrm{H}_{10}\right)_{0.5}$ and $0.7 \mathrm{Li}\left(\mathrm{CB}_{9} \mathrm{H}_{10}\right)-0.3 \mathrm{Li}\left(\mathrm{CB}_{11} \mathrm{H}_{12}\right) \cdot{ }^{[20,27]}$ The first compound crystallizes in a structure similar to the facecentered cubic high temperature structure of $\mathrm{Na}_{2} \mathrm{~B}_{10} \mathrm{H}_{10}$ with many partially occupied tetrahedral and octahedral sites for the $\mathrm{Na}^{+}$ions. ${ }^{[15]}$ The lithium mixed crystal crystallizes in the same space group $\left(\mathrm{P}_{1} \mathrm{c}\right)$ as the high temperature phase of $\mathrm{LiCB}_{9} \mathrm{H}_{10}$ and presents also partially occupied lithium sites, while the anions are centered on site $2 b(1 / 3,2 / 3, z){ }^{[25]}$

The contact between anion and cation appears to be quite specific, and anion reorientations and other low frequency lattice vibrations can induce fluctuations of the local potential which facilitate the cation mobility. This results in a range of values for the activation energy associated with the conductivity in the superionic phase between $c a$. $0.1 \mathrm{eV}$ for $\mathrm{NaCB}_{11} \mathrm{H}_{12} 0.3 \mathrm{eV}$ for $\mathrm{Na}_{2-\mathrm{x}}$ $\left(\mathrm{CB}_{11} \mathrm{H}_{12}\right)_{\mathrm{x}}\left(\mathrm{B}_{12} \mathrm{H}_{12}\right)_{1-\mathrm{x}}$, and $0.34 \mathrm{eV}$ for $\mathrm{Na}_{2}\left(\mathrm{~B}_{12} \mathrm{H}_{12}\right)_{0.5}\left(\mathrm{~B}_{10} \mathrm{H}_{10}\right)_{0.5}$ above $70{ }^{\circ} \mathrm{C} .{ }^{[26,86]}$ These interactions have been studied in detail recently for $\mathrm{Na}_{2}\left(\mathrm{~B}_{12} \mathrm{H}_{12}\right)_{0.5}\left(\mathrm{~B}_{10} \mathrm{H}_{10}\right)_{0.5}{ }^{[86]}$ Three different temperature regimes can be distinguished by impedance spectroscopy and have been further characterized using X-ray diffraction, NMR and QENS spectroscopies. In the lowest temperature regime (below $-50{ }^{\circ} \mathrm{C}$ ), the conductivity is very low and the activation energy is very high: $c a$. $0.8 \mathrm{eV}$. At $-50{ }^{\circ} \mathrm{C}$, a glasslike transition is observed, leading to a faster increase of the sodium conductivity. In the second regime, the apparent activation energy is found to be about $0.6 \mathrm{eV}$, while in the same temperature range, ${ }^{23} \mathrm{Na} \mathrm{NMR}$ experiments indicate a local barrier of $0.35 \mathrm{~V}$. The anion and cation motions are found to be coupled due to short range interactions. QENS experiments show that librational motions of the closo hydridoborate anions come here into play. Above $70{ }^{\circ} \mathrm{C}$, the thermal energy becomes larger than the background energy fluctuations and the activation barrier comes back to the value of $0.35 \mathrm{eV}$ found for the local energy barrier of the sodium ion.

The electrochemical stability of these materials is also remarkable: for $\mathrm{Na}_{2-\mathrm{x}}\left(\mathrm{CB}_{11} \mathrm{H}_{12}\right)_{\mathrm{x}}\left(\mathrm{B}_{12} \mathrm{H}_{12}\right)_{1-\mathrm{x}}$, an anodic peak is observed at $4.1 \mathrm{~V}$ vs Na$/ \mathrm{Na}$, while for $\mathrm{Na}_{2}\left(\mathrm{~B}_{12} \mathrm{H}_{12}\right)_{0.5}\left(\mathrm{~B}_{10} \mathrm{H}_{10}\right)_{0.5}$, the anodic peak started around $3 \mathrm{~V} \cdot{ }^{[20,26]} \mathrm{DFT}$ calculations on partially halogenated $\mathrm{B}_{12} \mathrm{H}_{12-\mathrm{X}} \mathrm{X}_{\mathrm{x}}^{2-}(\mathrm{X}=\mathrm{F}, \mathrm{Cl}, \mathrm{Br})$ ions in the gas phase of the vertical detachment energy (which is indirectly related to the electrochemical stability) show an increasing electrochemical stability with increasing halogen content. ${ }^{[87]}$

High-pressure experiments on $\mathrm{Na}_{2} \mathrm{~B}_{12} \mathrm{H}_{12}$ reveal two phase transitions observed at 0.5 and 5.7-8.1 GPa at room temperature. ${ }^{[88]}$ The bulk modulus of the first high pressure phase was found to be $\mathrm{B}_{0}=14.0 \pm 0.5 \mathrm{GPa}$, which shows that compared to oxide-based sodium ionic conductors $\mathrm{Na}_{2} \mathrm{~B}_{12} \mathrm{H}_{12}$ is much softer.

\section{Conclusions}

Boron hydrogen compounds are attractive materials for hydrogen storage, due to their high gravimetric hydrogen content. Thermodynamic studies confirm that the hydrogen release reactions are in the appropriate range for a safe storage. Many catalysts have been tested and shown to improve the kinetics of the dehydrogenation reactions, but not necessarily also the reverse reaction. It is very important to understand the detailed reaction mechanisms, which is the object of our current studies on $\mathrm{Mg}\left(\mathrm{BH}_{4}\right)_{2}$, in order to optimize the necessary catalysts. It appears that Lewis acid-base reactions are probably the key for these mechanisms.

Closo hydroborate-based and closo hydrocarborate solid ionic conductors show many promising properties for all-solid-state batteries: ${ }^{[89]}$ they have high conductivity at room temperature, they are chemically and electrochemically stable and also rather compressible. There appears to be scope for further improvements of these materials such as structure management by solid solutions using for instance partially halogenated closo hydridoborates or closo hydridocarborates. The current bottleneck here is the price, 
Table 1. Conductivity data of closo hydridoborate-based lithium and sodium ionic conductors

\begin{tabular}{|c|c|c|c|c|}
\hline Compound & $\begin{array}{l}\text { Phase transition } \\
\text { temperature }[K]\end{array}$ & $\begin{array}{c}\text { Conductivity above phase } \\
\text { transition }[\mathrm{S} / \mathrm{cm}]\end{array}$ & $\begin{array}{c}\text { Conductivity at } 300 \mathrm{~K} \\
{[\mathrm{~S} / \mathrm{cm}]}\end{array}$ & Ref. \\
\hline $\mathrm{Na}_{2} \mathrm{~B}_{10} \mathrm{H}_{10}$ & 380 & 0.01 & & {$[15]$} \\
\hline $\mathrm{Na}_{2} \mathrm{~B}_{12} \mathrm{H}_{12}$ & 539 & 0.1 & ca. $10^{-6}$ & {$[16]$} \\
\hline $\mathrm{Na}_{2} \mathrm{~B}_{12} \mathrm{H}_{12}$ ball milled & & & ca. $310^{-4}$ & {$[17]$} \\
\hline $\mathrm{Na}_{2} \mathrm{~B}_{12} \mathrm{H}_{12-\mathrm{x}} \mathrm{I}_{\mathrm{x}}$ & & $0.1(360 \mathrm{~K})$ & & {$[18]$} \\
\hline $\mathrm{Na}_{2} \mathrm{~B}_{10} \mathrm{H}_{10}-3 \mathrm{Na}_{2} \mathrm{~B}_{12} \mathrm{H}_{12}$ & - & & $3.210^{-4}$ & {$[19]$} \\
\hline $\mathrm{Na}_{2}\left(\mathrm{~B}_{12} \mathrm{H}_{12}\right)_{0.5}\left(\mathrm{~B}_{10} \mathrm{H}_{10}\right)_{0.5}$ & - & & $910^{-4}$ & {$[20]$} \\
\hline $\mathrm{LiNaB}_{12} \mathrm{H}_{12}$ & 514 & $0.79(550 \mathrm{~K})$ & & {$[21]$} \\
\hline $\mathrm{Na}_{2} \mathrm{~B}_{12} \mathrm{Cl}_{12}$ & 748 & 0.162 & & {$[22]$} \\
\hline $\mathrm{Na}_{2} \mathrm{~B}_{12} \mathrm{Br}_{12}$ & 798 & 0.08 & & {$[22]$} \\
\hline $\mathrm{Na}_{2} \mathrm{~B}_{12} \mathrm{I}_{12}$ & 843 & 0.03 & & {$[22]$} \\
\hline $\mathrm{Na}_{3} \mathrm{NH}_{2} \mathrm{~B}_{12} \mathrm{H}_{12}$ & - & & ca. $10^{-5}$ & {$[23]$} \\
\hline $\mathrm{NaCB}_{11} \mathrm{H}_{12}$ & & $0.12(383 \mathrm{~K})$ & & {$[24]$} \\
\hline $\mathrm{LiCB}_{11} \mathrm{H}_{12}$ & & $0.15(403 \mathrm{~K})$ & & {$[24]$} \\
\hline $\mathrm{NaCB}_{9} \mathrm{H}_{10}$ & & $0.05(323 \mathrm{~K})$ & & {$[25]$} \\
\hline $\mathrm{LiCB}_{9} \mathrm{H}_{10}$ & 355 & $0.04(357 \mathrm{~K})$ & & {$[25]$} \\
\hline $\mathrm{Na}_{2-\mathrm{x}}\left(\mathrm{CB}_{11} \mathrm{H}_{12}\right)_{\mathrm{x}}\left(\mathrm{B}_{12} \mathrm{H}_{12}\right)_{1-\mathrm{x}}$ & & & 0.002 & {$[26]$} \\
\hline $0.7 \mathrm{Li}\left(\mathrm{CB}_{9} \mathrm{H}_{10}\right)_{0.7}\left(\mathrm{CB}_{11} \mathrm{H}_{12}\right)_{0.3}$ & & & 0.0067 & {$[27]$} \\
\hline ' $\left[\mathrm{Li}_{2} \mathrm{~B}_{12} \mathrm{H}_{11+1 / \mathrm{n}}\right]_{\mathrm{n}}$ ' & & & $2.710^{-4}(308 \mathrm{~K})$ & {$[28]$} \\
\hline $\mathrm{NaB}_{11} \mathrm{H}_{14}$ & 353,361 & $0.045(413 \mathrm{~K})$ & ca. $710^{-6}$ & {$[29]$} \\
\hline $\mathrm{a}-\mathrm{NaB}_{11} \mathrm{H}_{14}{ }^{*}$ & & $0.023(413 \mathrm{~K})$ & ca. $10^{-3}$ & [29] \\
\hline $\mathrm{Na}\left[7-\mathrm{CB}_{10} \mathrm{H}_{13}\right]$ & 333 & $0.013(413 \mathrm{~K})$ & & [29] \\
\hline $\mathrm{Li}\left[7-\mathrm{CB}_{10} \mathrm{H}_{13}\right]$ & 340 & $0.0087(413 \mathrm{~K})$ & & [29] \\
\hline
\end{tabular}

* 'atypical' commercial sample with disordered cubic structure ${ }^{[29]}$

as there is presently only one commercial source of these materials. We have developed a safe and upscalable synthesis of $\mathrm{Na}_{2} \mathrm{~B}_{12} \mathrm{H}_{12}$ starting from $\mathrm{NaBH}_{4}$, which is the cheapest brohydride available.[44] This process was further improved to yield directly $\mathrm{Na}_{2}\left(\mathrm{~B}_{12} \mathrm{H}_{12}\right)_{0.5}\left(\mathrm{~B}_{10} \mathrm{H}_{10}\right)_{0.5}$ in five steps. ${ }^{[45]}$ The larger availability of these compounds is necessary to generalize the exploration for the optimal materials and for their eventual commercial applications.

\section{Acknowledgements}

This work was supported by the Swiss National Science Foundation (projects 200020-182494 and CRSII2_160749/1).

Received: August 7, 2019

[1] IEA, 'The Future of Hydrogen', IEA, Paris, 2019, www.iea.org/publications/reports/thefutureofhydrogen/ accessed July 22, 2019.

[2] J. Yang, A. Sudik, C. Wolverton, D. J. Siegel, Chem. Soc. Rev. 2010, 39, 656

[3] https://www.energy.gov/eerelfuelcells/downloads/doe-targets-onboard-hydrogen-storage-systems-light-duty-vehicles accessed July 22, 2019.

[4] B. R. S. Hansen, M. Paskevicius, H.-W. Li, E. Akiba, T. R. Jensen, Coord. Chem. Rev. 2016, 323, 60.

[5] M. Paskevicius, L. H. Jepsen, P. Schouwink, R. Černý, D.B. Ravnsbæk, Y. Filinchuk, M. Dornheim, F. Besenbacher, T. R. Jensen, Chem. Soc. Rev. 2017, 46, 1565 .
[6] Z. Wang, J. Parrondo, C. He, S. Sankarasubramanian, V. Ramani, Nature Energy 2019, 4, 281 .

[7] G. Moussa, R. Moury, U. B. Demirci, T. Sener, P. Miele, Int. J. Energy Res. 2013, 37, 825 .

[8] R. Černý, P. Schouwink, Acta Cryst. 2015, B71, 619.

[9] R. Mohtadi, A. Remhof, P. Jena, J. Phys. Condens. Matter. 2016, 28, 353001.

[10] R. Mohtadi, S. Orimo, Nat. Rev. Mater. 2016, 2, 16091.

[11] O. Zavorotynska, A. El-Kharbachi, S. Deledda, B. C. Hauback, Int. J. Hydrogen Energy 2016, 41, 14387.

[12] Y. Filinchuk, B. Richter, T. R. Jensen, V. Dmitriev, D. Chernyshov, H. Hagemann, Angew. Chem., Int. Ed. 2011, 50, 11162.

[13] Y. Zhang, E. Majzoub, V. Ozoliņš, C. Wolverton, J. Phys. Chem. C 2012, $116,10522$.

[14] G. Severa, E. Rönnebro, C. M. Jensen, Chem. Commun. 2010, 46, 421.

[15] T. J. Udovic, M. Matsuo, A. Unemoto, N. Verdal, V. Stavila, A. V. Skripov, J. J. Rush, H. Takamura, S. Orimo, Chem. Commun. 2014, 50, 3750.

[16] T. J. Udovic, M. Matsuo, W. S. Tang, H. Wu, V. Stavila, A. V. Soloninin, R. V. Skoryunov, O. A. Babanova, A. V. Skripov, J. J. Rush, A. Unemoto, H. Takamura, S. Orimo, Adv. Mater. 2014, 26, 7622.

[17] W. S. Tang, M. Matsuo, H. Wu, V. Stavila, A. Unemoto, S. Orimo, T. J. Udovic, Energy Storage Materials 2016, 4, 79.

[18] Y. Sadikin, P. Schouwink, M. Brighi, Z. Łodziana, R. Černý, Inorg. Chem. 2017, 56, 5006 .

[19] K. Yoshida, T. Sato, A. Unemoto, M. Matsuo, T. Ikeshoji, T. J. Udovic, S. I. Orimo, Appl. Phys. Lett. 2017, 110, 103901.

[20] L. Duchêne, R.S. Kühnel, E. Stilp, E. C. Reyes, A. Remhof, H. Hagemann, C. Battaglia, Energy Environ. Sci. 2017, 10, 2609.

[21] L. He, H.-W. Li, H. Nakajima, N. Tumanov, Y. Filinchuk, S.-J. Hwang, M. Sharma, H. Hagemann, E. Akiba, Chem. Mat. 2015, 27, 5483. 
[22] B. R. S. Hansen, M. Paskevicius, M. Jørgensen, T. R. Jensen, Chem. Mat. 2017, 29, 3423.

[23] L. He, H. Lin, H.-F. Li, Y. Filinchuk, J. Zhang, Y. Liu, M. Yang, Y. Hou, Y Deng, H.-W. Li, H. Shao, L. Wang, Z. Lu, J. Power Sources 2018, 396, 574

[24] W. S. Tang, A. Unemoto, W. Zhou, V. Stavila, M. Matsuo, H. Wu, S. Orimo, T. J. Udovic, Energy Environ. Sci. 2015, 8, 3637.

[25] W. S. Tang, M. Matsuo, H. Wu, V. Stavila, W. Zhou, A. A. Talin, A. V. Soloninin, R. V. Skoryunov, O. A. Babanova, A. V. Skripov, A. Unemoto, S. Orimo, T. J. Udovic, Adv. Energy Mater. 2016, 6, 1502237.

[26] M. Brighi , F. Murgia, Z. Łodziana, P. Schouwink, A. Wołczyk, R. Černý, J. Power Sources 2018, 404, 7 .

[27] S. Kim, H. Oguchi, N. Toyama, T. Sato, S. Takagi, T. Otomo, D. Arunkumar, N. Kuwata, J. Kawamura, S. Orimo, Nature Comm. 2019, 10, 1081.

[28] M. Zhu, Y. Pang, F. Lu, X. Shi, J. Yang, S. Zheng, ACS Appl. Mater. Interfaces 2019, 11, 14136 .

[29] W. S. Tang, M. Dimitrievska, V. Stavila, W. Zhou, H. Wu, A. A. Talin, T. J. Udovic, Chem. Mater. 2017, 29, 10496.

[30] C.-L. Yu, S. H. Bauer, J. Phys. Chem. Ref. Data 1998, 27, 807.

[31] B. I. Loukhovitski, S. A. Torokhov, E. E. Loukhovitskaya, A. S. Sharipov, Struct. Chem. 2018, 29, 49.

[32] M. Tho Nguyen, M. H. Matus, D. A. Dixon, Inorg. Chem. 2007, 46, 7561.

[33] R. Maillard, D. Sethio, H. Hagemann, L. M. Lawson Daku, ACS Omega 2019, 8786

[34] D. Sethio, L. M. Lawson Daku, H. Hagemann, E. Kraka, ChemPhysChem 2019, 20, 1967.

[35] A. Jezewska, B. Buszewski, Polish J. Chem. 2008, 82, 2233.

[36] D. R. Martin, J. Chem. Educ. 1959, 36, 208.

[37] M. A. Toft, J. B. Leach, F. L. Himpsl, S. G. Shore, Inorg. Chem. 1982, 21, 1952.

[38] L. Rude, U. Filso, V. D’Anna, A. Spyratou Stratmann, B. Richter, S. Hino, O. Zavorotynska, M. Baricco, M. H. Sørby, B. C. Hauback, H. Hagemann, F. Besenbacher, J. Skibsted, T. R. Jensen, Phys. Chem. Chem. Phys. 2013, 15, 8185.

[39] B. Richter, D. Ravnsbæk, M. Sharma, A. Spyratou Stratmann, H. Hagemann, T. R. Jensen, Phys. Chem. Chem. Phys. 2017, 19, 30157.

[40] C. Harzdorf, H. Niederprüm, H. Odenbach, Z. Naturforsch. B 1970, $25,6$.

[41] B. Gruner, V. Prochazka, J. Subrt, S. Hermanek, R. Pospech, Eur. J.. Solid State. Inorg. Chem. 1991, $28,597$.

[42] L. He, H.-W. Li, S.-J. Hwang, E. Akiba, J. Phys. Chem. C 2014, 118, 6084.

[43] L. He, Y. Fu, D. Wu, D. Zhang, H. Cheng, H. Lin, X. Li, W. Xionga, Q. Zhu, Y. Deng, H. Shao, H.-W. Li, X. Zhao, Z. Lu, Inorg. Chim. Acta 2018, 474, 16.

[44] R. Moury, A. Gigante, H. Hagemann, Int. J. Hydrogen Energy, 2017, 42, 22417.

[45] A. Gigante, L. Duchêne, R. Moury, M. Pupier, A. Remhof, H. Hagemann, ChemSusChem 2019, doi: 10.1002/cssc.201902152.

[46] L. V. Titov, P. V. Petrovskii, Russian J. Inorg. Chem. 2011, 56, 1032.

[47] N. S. Hosmane, J. R. Wermer, Z. Hong, T. D. Getman, S. G. Shore, Inorg. Chem. 1987, 26, 3638

[48] A. Ouassas, B. Frange, Bull. Soc. Chimique France 1986, 22.

[49] G. B. Dunks, K. Barker, E. Hedaya, C. Hefner, K. Palmer-Ordonez, P. Remec, Inorg. Chem. 1981, 20, 1692.

[50] P. P. Belov, P. A. Storozhenko, N. S. Voloshina, M. G. Kuznetsova, Russ. J. Appl. Chem. 2017, 90, 1804.

[51] G. B. Dunks, K. Palmer-Ordonez, Inorg. Chem. 1978, 17, 1514.

[52] A. Franken, B. T. King, J. Rudolph, P. Rao, B. C. Noll, J. Michl, Coll. Czech. Chem. Commun. 2001, 66, 1238.

[53] T. D. Getman, J. A. Krause, S. G. Shore, Inorg. Chem. 1988, 27, 2398.

[54] S. V. Ivanov, A. J. Lupinetti, S. M. Miller, O. P. Anderson, K. A. Solntsev, S. H. Strauss, Inorg. Chem. 1995, 34, 6419.

[55] T. Jelinek, P. Baldwin, W. R. Scheidt, C. A. Reed, Inorg. Chem. 1993, 32, 1982.

[56] D. Hnyk, J. Holub, A. Ruzicka, Z. Padelkova, M. Buhl, Struct. Chem. 2013, 24, 927.
[57] N. T. Kuznetsov, L. N. Kulikova, S. T. Zhukov, Zh. Neorg. Khimii 1976, 21, 96.

[58] W. H. Knoth, Jr., 'Neutral and singly charged derivatives of decaboranes and decaborates', U.S. patent, 1967, US 329626019670103.

[59] W. H. Knoth, H. C. Miller, J. C. Sauer, J. H. Balthis, Y. T. Chia, E. L. Muetterties, Inorg. Chem. 1964, 3, 159.

[60] H. C. Miller, N. E. Miller, E. L. Muetterties, Inorg. Chem. 1964, 3, 1456.

[61] L. V. Titov, E. R. Eremin, V. Y. Rosolovskii, Russ. J. Inorg Chem. 1982, 27, 500.

[62] A. S. Leonard, J. Am. Rocket Soc. 1947, 72, 10

[63] A. Franken, J. D. Kennedy, J. Clapper, L. G. Sneddon, Inorg. Synth. 2014, $36,174$.

[64] M. F. Hawthorne, A. R. Pitochelli, R. D. Strahm, J. J. Miller, J. Am. Chem. Soc. 1960, 82,1825

[65] E. Callini, A. Borgschulte, A.J. Ramirez-Cuesta, A. Züttel, Dalton Trans. 2013, 42, 719 .

[66] A. Borgschulte, E. Callini, B. Probst, A. Jain, S. Kato, O. Friedrichs, A. Remhof, M. Bielmann, A. J. Ramirez-Cuesta, A. Züttel, J. Phys. Chem. C 2011, 115, 17220 .

[67] O. Friedrichs, A. Borgschulte, S. Kato, F. Buchter, R. Gremaud, A. Remhof, A. Züttel, Chem. Eur. J. 2009, 15, 5531.

[68] P. Schouwink, Y. Sadikin, W. van Beek, R. Černý, Int. J. Hydrogen Energy 2015, 40, 10902.

[69] Y. Yue, L. Chen, J. Peng, J. Energetic Materials 2018, 36, 82.

[70] M. W. Chase, 'NIST-JANAF Thermochemical Tables'2 Volume-Set (Journal of Physical and Chemical Reference Data Monographs), 1998.

[71] H. Hagemann, V. D'Anna, J.-P. Rapin, K. Yvon, J. Phys. Chem. C 2010, 114,10045 .

[72] M. Sharma, D. Sethio, V. D’Anna, J. C. Fallas, P. Schouwink, R. Černý, H. Hagemann, J. Phys. Chem. C, 2015, 119, 29.

[73] Z. Huang, Y. Wang, D. Wang, F. Yang, Z. Wu, L. Wua, Z. Zhang, Phys. Chem. Chem. Phys. 2019, 21, 11226.

[74] M. Heere, O. Zavorotynska, S. Deledda, M. H. Sørby, D. Book, T. Steriotis, B. C. Hauback, RSC Adv. 2018, 8, 27645.

[75] H. W. Li, K. Kikuchi, Y. Nakamori, K. Miwa, S. Towata, S. Orimo, Scr. Mater. 2007, 57, 679.

[76] I. Saldan, C. Frommen, I. Llamas-Jansa, G. N. Kalantzopoulos, S. Hino, B. Arstad, R. H. Heyn, O. Zavorotynska, S. Deledda, M. H. Sørby, H. Fjellvåg, B. C. Hauback, Int. J. Hydrogen Energy 2015, 40, 12286.

[77] M. Chong, T. Autrey, C. Jensen, Inorganics 2017, 5, 89.

[78] M. Chong, M. Matsuo, S. Orimo, T. Autrey, C. M. Jensen, Inorg. Chem 2015, 54, 4120 .

[79] C. Sugai, S. Kim, G. Severa, J. L. White, N. Leick, M. B. Martinez, T. Gennett, V. Stavila, C. Jensen, ChemPhysChem 2019, 20, 1301.

[80] G. Severa, E. Ronnebro, C. M. Jensen, Chem. Commun. 2010, 46, 421.

[81] R. J. Newhouse, V. Stavila, S.-J. Hwang, L. E. Klebanoff, J. Z. Zhang, J. Phys. Chem. C 2010, 114, 5224.

[82] S. Y. Kang, T. W. Heo, M. D. Allendorf, B. C. Wood, ChemPhysChem 2019, $20,1340$.

[83] M. Aniya, Solid State Ionics 1992, 50, 125

[84] E. L. Muetterties, J. H. Balthis, Y. T. Chia, W. H. Knoth, H. C. Miller, Inorg. Chem. 1964, 3, 444.

[85] K. E. Kweon, J. B. Varley, P. Shea, N. Adelstein, P. Mehta, T. Wook Heo, T. J. Udovic, V. Stavila, B. C. Wood, Chem. Mat. 2017, 29, 9142.

[86] L. Duchêne, S. Lunghammer, T. Burankova, W.-C. Liao, J. P. Embs, C. Copéret, H. M. R. Wilkening, A. Remhof, H. Hagemann, C. Battaglia, Chem Mat. 2019, 31, 3449.

[87] M. Sharma, D. Sethio, L. M. Lawson Daku, H. Hagemann, J. Phys. Chem. A 2019, 123, 1807.

[88] R. Moury, Z. Lodziana, A. Remhof, L. Duchêne, E. Roedern, A. Gigante, H. Hagemann, Acta Cryst B 2019, B75, 406.

[89] L. Duchêne, A. Remhof, H. Hagemann, C. Battaglia, Energy Storage Materials 2019, doi:10.1016/j.ensm.2019.08.032. 